\title{
ANALISIS STRATEGI PEMBELAJARAN SILENT DEMONSTRATION DAN INFORMATION REASERCH PADA MATA PELAJARAN IPA DI SD/MI
}

\author{
Dewi Masita \\ Institut Agama Islam (IAI) Muhammadiyah Bima \\ Email: masithadewi.21@gmail.com
}

\begin{abstract}
Abstrak
Pelaksanaan pembelajaran disekolah dengan menggunakan strategi pembelajaran aktif merupakan upaya kontekstual yang dilakukan oleh guru dalam rangka menciptakan suasana pembelajaran yang menyenangkan dan sesuai dengan kenyataan yang dialami oleh peserta didik. Pada pembelajaran materi IPA di SD/MI mesti harus menggunakan strategi dan langkah-langkah pembelajaran yang dapat mempermudah guru dalam mentransformasikan pengetahuan, sikap dan keterampilan sesuai dengan standar kompetensi, kompetensi dasar, indikator dan tujuan pembelajaran. Adapun strategi pembelajaran yang diterapkan dalam pembelajaran yang menyenangkan dan kontekstual adalah strategi pembelajaran Silent Demonstration dan information reaserch. Dua strategi pembelajaran ini memiliki kesesuaiannya dengan materi dan langkah-langkah pembelajaran, sehingga proses pembelajaran berlangsung efektif dan sesuai dengan tujuan pembelajaran. Dalam tulisan ini dapat ditarik sebuah kesimpulan, guru harus dapat memahami bahwa dalam proses pembelajaran pada mata pelajaran IPA di SD/MI tidak semua materi cocok untuk semua metode, tidak semua materi cocok untuk semua media, tidak semua pembelajaran memerlukan seluruh urutan pembelajaran, urutan kegiatan pembelajaran tergantung pada karakteristik siswa dan jenis perilaku yang ada dalam tujuan pembelajaran. Dengan demikian , dalam menentukan strategi pembelajaran diperlukan pemilihan, dan sedapat mungkin disusun berdasarkan alasan-alasan yang bersifat rasional.
\end{abstract}

Kata Kunci: Strategi Pembelajaran, Pelajaran IPA, SD/MI

\section{PENDAHULUAN}

$\mathrm{P}$ endidikan adalah hal yang sangat penting karena pendidikan merupakan suatu proses yang dilakukan secara sadar atau disengaja guna untuk menambah pengetahuan, wawasan serta pengalaman untuk menentukan tujuan hidup sehingga bisa memiliki pandangan yang luas untuk masa depan yang lebih baik. Dengan 
pendidikan seseorang memperoleh pengetahuan dan pandangan serta wawasan yang luas sehingga dapat meningkatkatkan mutu dan taraf kehidupan dalam berbagai dimensi kehidupan sehari-hari dalam bermasyrakat.Tujuan pendidikan indonesia yang sesuai dengan UndangUndang Dasar No 20 Tahun 2003 tentang tujuan pendidikan Nasional yaitu bahwa pendidikan di Indonesia bertujuan untuk berkembangnya potensi agar manusia menjadi makhluk yang beriman dan bertaqwa kepada Tuhan Yang Maha Esa, berakhlak mulia, sehat, berilmu, cakap dan kreatif, mandiri dan menjadi warga negara yang bertanggung jawab (Muhammad Afandi, 2013).

Tugas pendidikan adalah tugas kemanusiaan. Manusia yang berpotensi itu dapat berkembang ke arah yang baik, tetapi dapat pula berkembang kearah yang tidak baik. Karena itulah maka diperlukan berbagai usaha yang didasari sepenuhnya dan dirancang secara sistematis agar perkembangan itu menuju ke hal-hal yang baik. Dengan pendidikan harkat dan martabat manusia ditingkatkan sampai setinggitingginya. Di dalam sejarah dunia pendidikan guru merupakan sosok figur teladan bagi siswa yang harus memiliki strategi dan teknik-teknik dalam mengajar.

Kegiatan belajar mengajar sebagai sistem intruksional merupakan interaksi antara siswa dengan komponen-komponen lainnya, dan guru sebagai pengelola kegiatan pembelajaran agar lebih aktif dan efektif secara optimal. Salah satu yang harus dipertimbangkan dalam pembelajaran adalah pemilihan strategi yang sesuai dengan tema dan sesuai dengan karakteristik perkembangan anak.

Realitanya, peserta didik memiliki cara belajar yang berbedabeda, beberapa peserta didik lebih suka belajar dengan membaca,beberapa suka berdiskusi dan ada pula yang suka praktek secara langsung. Oleh karenanya diperlukan strategi pembelajaran aktif yang variatif agar tidak terjadi kejenuhan dalam proses pembelajaran sehingga dapat membantu peserta didik dalam memaksimalkan potensi dirinya. 


\section{TINJAUAN TEORITIS}

\section{Pengertian Strategi pembelajaran}

Istilah strategi berasal dari bahasa Yunani, yaitu strategia. Strategi merupakan sebuah perencanaan yang panjang untuk berhasil dalam mencapai suatu keuntungan. Demikian juga strategi didefinisikan sebagai suatu garis besar haluan bertindak untuk mencapai sasaran yang telah ditetapkan (Martinis Yamin, 2012).

Dalam dunia pendidikan, strategi diartikan sebagai a plan, method, or series of activities designed to achieves a particular educational goal (J.R. David, 1976). dengan demikian strategi pembelajaran dapat diartikan sebagai perencanaan yang berisi tentang rangkaian kegiatan yang didesain untuk mencapai tujuan pendidikan tertentu. Dengan demikian, penyusunan langkah-langkah pembelajaran, pemanfaatan berbagi fasilitas dan sumber belajar semuanya di arahkan dalam upaya pencapaian tujuan. Oleh sebab itu, sebelum menetukan strategi, perlu dirumuskan tujuan yang jelas yang dapat diukur keberhasilannya, sebab tujuan adalah rohnya dalam implementasi suatu strategi (Wina Sanjaya, 2007).

Rumusan lebih jelas dapat dilihat dalam Depdiknas yang merumuskan strategi pembelajaran sebagai cara pandang dan pola pikir guru dalam mengajar agar pembelajaran menjadi efektif. Artinya, rumusan yang dibuat Depdiknas lebih spesifik dengan tujuan yang jelas, yaitu meningkatkan efektivitas pembelajaran. Rumusan Depdiknas tersebut diperkuat dengan pernyataan selanjutnya bahwa dalam mengembangkan strategi pembelajaran, guru perlu mempertimbangkan beberapa hal yang memungkinkan terciptanya pembelajaran efektif dan berhasil baik (Darmansyah, 2012).

Strategi pembelajaran merupakan pengorganisasian isi pelajaran, penyampaian pelajaran dan pengelolaan kegiatan belajar dengan menggunakan berbagai sumber belajar yang dapat dilakukan guru untuk 
mendukung terciptanya evektifitas dan efisiensi proses pembelajaran. Romiszowski mengungkapkan strategi adalah sebagai titik pandang dan arah berbuat yang diambil dalam rangka memilih metode pembelajaran yang tepat, yang selanjutnya mengarah pada yang lebih khusus, yaitu rencana, taktik, dan latihan. Regeluth juga menyatakan konsep yang tidak jauh berbeda, bahwa strategi pembelajaran merupakan cara pandang dan pola pikir guru dalam mengajar (Darmansyah, 2012).

Berdasarkan pemaparan di atas peneliti mengaitkan bagaimana upaya mengimplementasikan rencana yang sudah disusun dalam kegiatan nyata agar tujuan yang telah disusun tercapai secara optimal dengan cara strategi pembelajaran yaitu cara pandang, pola berpikir dan arah berbuat yang diambil guru dalam memilih metode pembelajaran yang memungkinkan efektifnya pembelajaran.

Sebagaimana dikemukakan kesimpulan di atas, pemilihan strategi harus sesuai dengan tujuan pembelajaran sehingga peneliti dalam memilih strategi pembelajaran paling tidak didasarkan dua argumentasi. Pertama, strategi yang disusun didukung dengan teori-teori psikologi dan teori pembelajaran. Kedua, strategi yang disusun menunjukkan efektivitas dalam membuat siswa mencapai tujuan pembelajaran seperti yang telah ditetapkan. Argumentasi ini diperlukan karena didalam pembelajaran dipahami bahwa:" tidak semua materi cocok untuk semua metode, tidak semua materi cocok untuk semua media, tidak semua pembelajaran memerlukan seluruh urutan pembelajaran, urutan kegiatan pembelajaran tergantung pada karakteristik siswa dan jenis perilaku yang ada dalam tujuan pembelajaran". Dengan demikian, dalam menentukan strategi pembelajaran diperlukan pemilihan, dan sedapat mungkin disusun berdasarkan alasan-alasan yang bersifat rasional (Trianto, 2015).

\section{Macam - Macam Strategi Pembelajaran}

a. Information Search

Metode ini sama saja dengan ujian open book. Secara berkelompok siswa mencari informasi yang menjawab pertanyan-pertanyaan yang diberikan kepada mereka. Metode 
ini sangat membantu pelajaran untuk lebih menghidupkan materi yang di anggap kering.

Langkah-langkah:

1) Membuat beberapa peratanyaan yang dapat dijawab dengan mencari informasi dari alat peraga

2) Berikan pertanyaan-pertanyaan tersebut kepada siswa

3) Minta siswa menjawab pertanyaan bisa Individi atau kelompok kecil

4) Beri komentar atas jawaban yang diberikan siswa. Kembangkan jawaban untuk memperluas skope pembelajaran (Trianto, 2015).

b. Silent Demonstration

Straegi ini dapat digunakan untuk mengajar langkahlangkah suatu proses atau keterampilan yang lain. Dengan mendemonstrasikan langkah-langkah suatu prosedur dengan cara diam (Bisu). Anda mendorong siswa untuk tetepa menjaga perhatian. Strategi ini dapat digunakan dengan baik unuk mengajarkan keterampilan atau materi-materi yang menuntut kerja psikomotorik.

Langkah-langkah:

1) Tentukan Prosedur atau langkah-langkah yang akan diajarkan siswa. Penggunaan Alat peraga,

2) Siswa mengamati guru dalam memberikan gambaran visual tentang prosedur sesuatu,

3) Siswa berpasang-pasangan kemudian siswa dimina mendemonstrasikan lagi bagian pertama prosedur,

4) Meminta beberapa orang unuk menjelaskan apa yang anda lakukan. Komentari observasi yang benar,

5) Berikan kesempatan masing-masing pasangan untuk mempraktekkan prosedur, 
6) Akhiri dengan memberikan tantangan kepada siswa untuk melakukan prosedur dari awal sampai akhir (Trianto, 2015).

\section{PEMBAHASAN}

Peneliti menganalisa tema 2 selalu berhemat energi dengan subtema 1 macam-macam energi pada pembelajaran 2 mata pelajaran ilmu pengetahuan alam di kelas IV Berikut hasil analisa peneliti terkait strategi-strategi yang terdapat dalam langkah-langkah pembelajaran buku tematik kelas IV tema 2 selalu berhemat energi subtema 1 macammacam energi pada pembelajaran 2:

\section{Analisis Strategi Pembelajaran}

a. Kompetensi Dasar IPA:

3.4 Membedakan berbagai bentuk energi melalui pengamatan dan mendeskripsikan pemanfaatannya dalam kehidupan seharihari.

3.5 Menyajikan laporan hasil pengamatan tentang teknologi yang digunakan di kehidupan sehari-hari serta kemudahan yang diperoleh oleh masyarakat dengan memanfaatkan teknologi tersebut.

b. Indikator:

- Menjelaskan melalui tulisan laporan tentang pemanfaatan sumber energi angin dan air, dalam kehidupan

c. Tujuan pembelajaran:

Dengan percobaan dan pengamatan, siswa mampu membandingkan melalui tulisan tentang manfaat energi angin dan energi air serta pemanfaatan kincir air dan kincir angin dalam kehidupan sehari-hari berdasarkan data hasil percobaan

d. Langkah-langkah pembelajaran dalam buku tematik pada Kompetensi Dasar IPA (halaman 14-15):

1) Sebagai kegiatan pembuka, siswa mengamati gambar kincir yang ada pada buku.

2) Siswa membuat perkiraan tentang kincir angin:Apa yang membuat kincir berputar? (ditiup angin), Sumber energi apa yang bisa menggerakkan kincir itu? (angin), Bentuk energi apa 
yang timbul saat kincir berputar? (gerakan) Apa manfaat kincir angin dalam kehidupan seharihari? (untuk bermain, sebagai benda perantara yang mengubah sumber energi angin menjadi bentuk energi gerak pada baling-baling, dan mengakibatkan pompa bergerak memompa air)

3) Siswa menjawab rumusan masalah tersebut dengan cara diskusi berpasangan bersama teman sebangku untuk menemukan jawabannya. Kegiatan ini untuk melatih keterampilan sains siswa dalam membuat "Hipotesis" (dugaan sementara) dari rumusan masalah.

4) Siswa keluar kelas dan melakukan percobaan kincir tersebut

5) Siswa menggerakkan kincir angin dengan membawanya berlari atau ditiup.

6) Siswa menggerakkan kincir air dengan cara mengucurkan air dari atas kincir, pastikan air jatuh tepat di atas baling-baling.

7) Siswa mengamati proses percobaan hingga kincir bergerak berputar.

8) Siswa mencocokkan jawaban sementara mereka di awal pembelajaran dengan hasil percobaan.

\section{Penerapan Strategi Pembelajaran Pada Mata Pelajaran IPA di} SD/MI

Berdasarkan langkah-langkah yang terdapat pada buku tematik di atas, peneliti menganalisis strategi yang digunakan sehingga peneliti memilih dua strategi yang hampir mendekati kesesuaian dengan langkah-langkah tersebut kemudian dii analisis kembali agar menjadi satu kesimpulan dan satu strategi yang menurut peneliti sangat sesui. Adapun pertimbangan strategi yang peneliti ajukan sebagai berikut: 
a. Strategi Pembelajaran Information Search (Mencari Informasi)

\begin{tabular}{|c|c|c|c|}
\hline Strategi dan Langkah Pembelajaran & $\begin{array}{lr}\text { Membuat } & \text { beberapa } \\
\text { peratanyaan } & \text { yang } \\
\text { dapat } & \text { dijawab } \\
\text { dengan } & \text { mencari } \\
\text { informasi } & \text { dari } \text { alat } \\
\text { peraga } & \end{array}$ & $\begin{array}{l}\text { Minta siswa } \\
\text { menjawab } \\
\text { pertanyaan bisa } \\
\text { Individi atau } \\
\text { kelompok kecil }\end{array}$ & $\begin{array}{c}\text { Beri } \\
\text { komentar } \\
\text { atas jawaban } \\
\text { yang } \\
\text { diberikan } \\
\text { siswa. } \\
\text { Kembangkan } \\
\text { jawaban } \\
\text { untuk } \\
\text { memperluas } \\
\text { skope } \\
\text { pembelajaran }\end{array}$ \\
\hline $\begin{array}{l}\text { 1.Sebagai kegiatan pembuka, siswa } \\
\text { mengamati gambar kincir yang ada pada } \\
\text { buku. }\end{array}$ & $\sqrt{ }$ & & \\
\hline $\begin{array}{l}\text { 2.Siswa membuat perkiraan tentang kincir } \\
\text { angin:Apa yang membuat kincir berputar? } \\
\text { (ditiup angin), Sumber energi apa yang } \\
\text { bisa menggerakkan kincir itu? (angin), } \\
\text { Bentuk energi apa yang timbul saat kincir } \\
\text { berputar? (gerakan) Apa manfaat kincir } \\
\text { angin dalam kehidupan seharihari? (untuk } \\
\text { bermain, sebagai benda perantara yang } \\
\text { mengubah sumber energi angin menjadi } \\
\text { bentuk energi gerak pada baling-baling, } \\
\text { dan mengakibatkan pompa bergerak } \\
\text { memompa air) }\end{array}$ & & & \\
\hline $\begin{array}{l}\text { 3.Siswa menjawab rumusan masalah } \\
\text { tersebut dengan cara diskusi berpasangan } \\
\text { bersama teman sebangku untuk } \\
\text { menemukan jawabannya. Kegiatan ini } \\
\text { untuk melatih keterampilan sains siswa } \\
\text { dalam membuat "Hipotesis" (dugaan } \\
\text { sementara) dari rumusan masalah. }\end{array}$ & & $\sqrt{ }$ & \\
\hline $\begin{array}{l}\text { 4.Siswa keluar kelas dan melakukan } \\
\text { percobaan kincir tersebut }\end{array}$ & & & \\
\hline $\begin{array}{l}\text { 5.Siswa menggerakkan kincir angin dengan } \\
\text { membawanya berlari atau ditiup. }\end{array}$ & & & \\
\hline $\begin{array}{l}\text { 6. Siswa menggerakkan kincir air dengan } \\
\text { cara mengucurkan air dari atas kincir, } \\
\text { pastikan air jatuh tepat di atas baling- }\end{array}$ & & & \\
\hline
\end{tabular}




\begin{tabular}{|l|l|l|l|}
\hline baling. & & & \\
\hline $\begin{array}{l}\text { 7.Siswa mengamati proses percobaan hingga } \\
\text { kincir bergerak berputar. }\end{array}$ & & & \\
\hline $\begin{array}{l}\text { 8. Siswa mencocokkan jawaban sementara } \\
\text { mereka di awal pembelajaran dengan hasil }\end{array}$ & & & \\
percobaan. & & & \\
\hline
\end{tabular}

b. Strategi Pembelajaran Silent Demonstrasion (Demonstrasi Bisu)

\begin{tabular}{|c|c|c|c|}
\hline Strategi dan Langkah Pembelajaran & $\begin{array}{c}\text { Tentukan Prosedur / } \\
\text { langkah - langkah } \\
\text { yang akan diajarkan } \\
\text { siswa. Penggunaan } \\
\text { Alat peraga }\end{array}$ & $\begin{array}{l}\text { Siswa mengamati } \\
\text { guru dalam } \\
\text { memberikan } \\
\text { gambaran visual } \\
\text { tentang prosedur } \\
\text { sesuatu. }\end{array}$ & $\begin{array}{c}\text { Akhiri dengan } \\
\text { memberikan } \\
\text { tantangan kepada } \\
\text { siswa untuk } \\
\text { melakukan } \\
\text { prosedur dari awal } \\
\text { sampai akhir. }\end{array}$ \\
\hline \multicolumn{4}{|l|}{$\begin{array}{l}\text { 1.Sebagai kegiatan pembuka, } \\
\text { siswa mengamati gambar kincir } \\
\text { yang ada pada buku. }\end{array}$} \\
\hline \multicolumn{4}{|l|}{$\begin{array}{l}\text { 2.Siswa membuat perkiraan } \\
\text { tentang kincir angin:Apa yang } \\
\text { membuat kincir berputar? (ditiup } \\
\text { angin), Sumber energi apa yang } \\
\text { bisa menggerakkan kincir itu? } \\
\text { (angin), Bentuk energi apa yang } \\
\text { timbul saat kincir berputar? } \\
\text { (gerakan) Apa manfaat kincir } \\
\text { angin dalam kehidupan } \\
\text { seharihari? (untuk bermain, } \\
\text { sebagai benda perantara yang } \\
\text { mengubah sumber energi angin } \\
\text { menjadi bentuk energi gerak } \\
\text { pada baling-baling, dan } \\
\text { mengakibatkan pompa bergerak } \\
\text { memompa air) }\end{array}$} \\
\hline $\begin{array}{l}\text { 3.Siswa menjawab rumusan } \\
\text { masalah tersebut dengan cara } \\
\text { diskusi berpasangan bersama } \\
\text { teman sebangku untuk } \\
\text { menemukan jawabannya. } \\
\text { Kegiatan ini untuk melatih } \\
\text { keterampilan sains siswa dalam } \\
\text { membuat "Hipotesis" (dugaan } \\
\text { sementara) dari rumusan } \\
\text { masalah. }\end{array}$ & & & \\
\hline $\begin{array}{l}\text { 4.Siswa keluar kelas } \\
\text { melakukan percobaan } \\
\text { tersebut }\end{array}$ & & & \\
\hline
\end{tabular}




\begin{tabular}{|c|c|}
\hline \begin{tabular}{|ll} 
5.Siswa menggerakkan kincir \\
angin dengan membawanya \\
berlari atau ditiup.
\end{tabular} & \\
\hline $\begin{array}{l}\text { 6. Siswa menggerakkan kincir air } \\
\text { dengan cara mengucurkan air } \\
\text { dari atas kincir, pastikan air jatuh } \\
\text { tepat di atas baling-baling. }\end{array}$ & \\
\hline $\begin{array}{lll}\text { 7.Siswa mengamati } & \text { proses } \\
\text { percobaan hingga } & \text { kincir } \\
\text { bergerak berputar. } & \\
\end{array}$ & $\sqrt{ }$ \\
\hline $\begin{array}{l}\text { 8. Siswa mencocokkan jawaban } \\
\text { sementara mereka di } \\
\text { pembelajaran dengan } \\
\text { percobaan. }\end{array}$ & \\
\hline
\end{tabular}

Berdasarkan analisis di atas peneliti memberikan nilai setiap langkah pembelajaran yang ada pada buku guru dengan angka 20 per aitemnya (langkah no 4,5 dan 6 dihitung satu aitem) agar memudahkan dalam penyeleksian strategi yang paling mendekati, dari paparan langkah-langkah yang telah ada dan berbagai alasan yang peneliti ungkapkan sebagai penguat dari hasil analisis yaitu sebagai berikut:

a. Information Search (Mencari Informasi)

Berdasarkan analisis di atas dapat ditarik kesimpulan bahwa komponen dari langkah-langkah Information Search mencakup $60 \%$ dari langkah-langkah yang tertuang pada buku guru sehingga komponen yang belum terpenuhi sebanyak $40 \%$ dari $100 \%$ yang mencakup semua komponen langkah -langkah pada buku guru.

b. Silent Demonstration (Demonstrasi Bisu)

Berdasarkan analisis di atas dapat ditarik kesimpulan bahwa komponen dari langkah-langkah Silent Demonstration mencakup $80 \%$ dari langkah-langkah yang tertuang pada buku guru sehingga komponen yang belum terpenuhi sebanyak $20 \%$ dari $100 \%$ yang mencakup komponen langkah-langkah pada buku guru. Agar lebih jelas dalam penyampaian data, peneliti menyajikan dalam diagram yang dapat dilihat di bawah ini. 


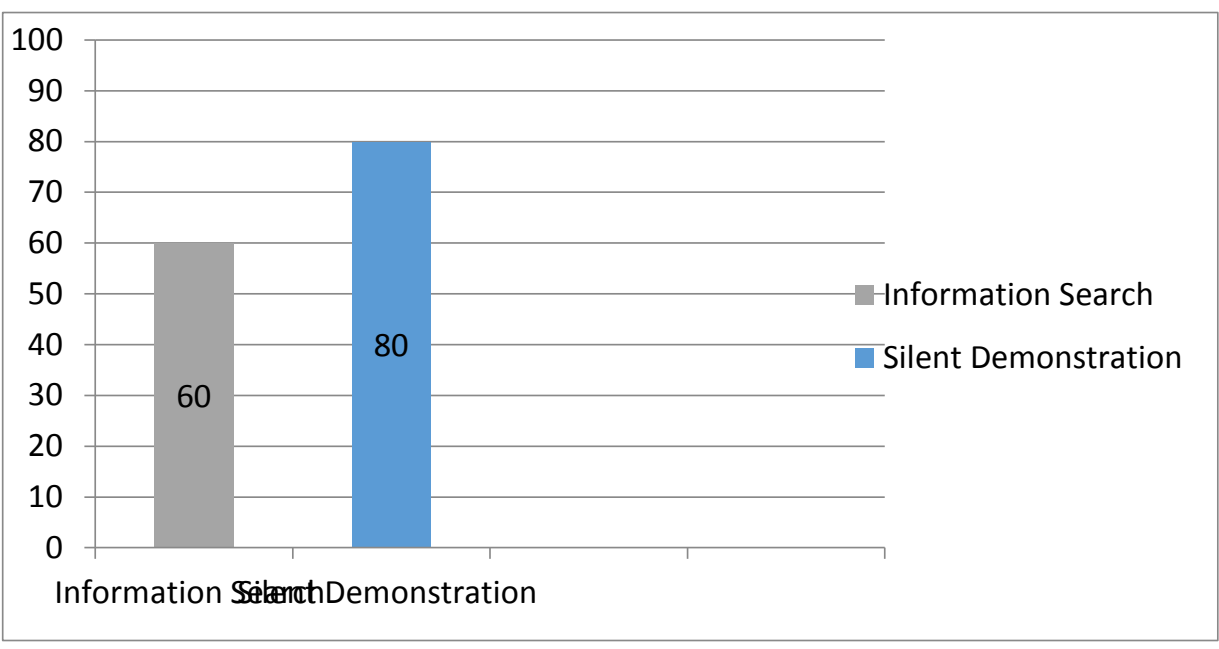

Bisa disimpulkan dari diagram di atas bahwa strategi Silent Demonstration lebih unggul dibandingkan dengan strategi Information Search dikarenakan dalam langkah-langkah strategi Silent Demonstration hampir mendekati dengan langkah-langkah yang ada pada langkah-langkah di buku guru. Tidak hanya itu saja dalam penilaian sikap (rasa Ingin tahu, kerja sama, tekun, teliti) bisa diwujudkan dengan menggunakan strategi Silent Demonstration tetapi dalam tujuan pembelajaran yaitu dengan percobaan dan pengamatan, siswa mampu membandingkan melalui tulisan tentang manfaat energi angin dan energi air serta pemanfaatan kincir air dan kincir angin dalam kehidupan sehari-hari berdasarkan data hasil percobaan belum bisa mencakup dalam pembelajaran karena strategi ini dapat digunakan dengan baik unuk mengajarkan keterampilan atau materi-materi yang menuntut kerja psikomotorik sehingga aspek kognitifnya belum mencakup sebagaimana tujuan yang ingin dicapai pada pembelajaran. Sehingga peneliti melanjutkan ke tahap pengembangan yaitu dengan cara mengolaborasikan beberapa strategi yang dapat dilihat di bagian selanjutnya.

\section{Pengembangan Analisis Strategi Pembelajaran Menggunakan Kolaborasi}

Berbagai informasi yang telah peneliti paparkan di bagian pertama tentang analisis strategi pembelajaran 2 yang dikaji dan menyimpulkan pendekatan yang sesuai tanpa kolaborasi, tetapi 
dilahat dari aspek indikator, tujuan pembelajaran, langkah-langkah pembelajaran, dan langkah-langkah strategi pembelajaran belum sepenuhnya terpenuhi ataupun sesuai, maka dari itu penelitii mengkolaborasikan strategi yang satu dengan strategi lain sehingga terjadinya kontribusi yang dapat menunjang pembelajaran siswa menjadi lebih baik. Adapun kolaborasi yang peneliti ajukan sebagai berikut:

a. Information Search

Metode ini sama saja dengan ujian open book. Secara berkelompok siswa mencari informasi yang menjawab pertanyanpertanyaan yang diberikan kepada mereka. Metode ini sangat membantu pelajaran untuk lebih menghidupkan materi yang di anggap kering.

Langkah-langkah:

1) Membuat beberapa peratanyaan yang dapat dijawab dengan mencari informasi dari alat peraga

2) Berikan pertanyaan-pertanyaan tersebut kepada siswa

3) Minta siswa menjawab pertanyaan bisa Individi atau kelompok kecil

4) Beri komentar atas jawaban yang diberikan siswa. Kembangkan jawaban untuk memperluas skope pembelajaran

b. Silent Demonstration

Straegi ini dapat digunakan untuk mengajar langkahlangkah suatu proses atau keterampilan yang lain. Dengan mendemonstrasikan langkah-langkah suatu prosedur dengan cara diam (Bisu). Anda mendorong siswa untuk tetepa menjaga perhatian. Strategi ini dapat digunakan dengan baik unuk mengajarkan keterampilan atau maeri-materi yang menuntut kerja psikomotorik. 
Langkah-langkah:

1) Tentukan Prosedur atau langkah-langkah yang akan diajarkan siswa. Penggunaan Alat peraga,

2) Siswa mengamati guru dalam memberikan gambaran visual tentang prosedur sesuatu,

3) Siswa berpasang-pasangan kemudian siswa dimina mendemonstrasikan lagi bagian pertama prosedur,

4) Meminta beberapa orang unuk menjelaskan apa yang anda lakukan. Komentari observasi yang benar,

5) Berikan kesempatan masing-masing pasangan untuk mempraktekkan prosedur,

6) Akhiri dengan memberikan tantangan kepada siswa untuk melakukan prosedur dari awal sampai akhir.

Berdasarkan langkah-langkah dari berbagai strategi di atas, penelitii mengkolaborasi langkah-langkah tersebut sehingga menjadi satu langkah-langkah strategi sebagai berikut:

1) Membuat beberapa pertanyaan yang dapat dijawab dengan mencari informasi dari alat peraga sebanding dengan Siswa mengamati guru dalam memberikan gambaran visual tentang prosedur sesuatu;

2) Tentukan Prosedur atau langkah-langkah yang akan diajarkan siswa. Penggunaan Alat peraga sebanding dengan Berikan pertanyaan-pertanyaan tersebut kepada siswa dan Sampaikan beberapa pertanyaan kepada siswa untuk mengetahui pikiran dan kemampuan yang mereka miliki. Guna pertanyaan-peranyaan yang mempunyai beberapa kemungkinan jawaban,

3) Berikan waktu beberapa menit untuk memberikan kesempatan kepada siswa untuk menjawab pertanyaan. Anjurkan mereka untuk bekerja berdua atau dalam kelompok kecil sebanding dengan 
Minta siswa menjawab pertanyaan bisa Individi atau kelompok kecil,

4) Siswa berpasang-pasangan. Kemudian siswa diminta mendemonstrasikan lagi bagian pertama prosedur;

5) Meminta beberapa orang unuk menjelaskan apa yang anda lakukan. Komentari observasi yang benar;

6) Berikan kesempatan masing-masing pasangan untuk mempraktekkan prosedur,

7) Minta siswa menyampaikan hasil jawaban mereka dan catat jawaban-jawaban yang mereka sampaikan sebanding dengan Beri komentar atas

\section{SIMPULAN}

Bila dipahami lebih dalam guru agar lebih kreatif dan inovatif, hendaknya guru juga harus mengembangkan strategi yang sudah ada dan tidak bergantung secara terus menerus pada langkah-langkah pembelajaran buku tematik kurikulum 2013. Pemilihan strategi pembelajaran paling tidak didasarkan dua argumentasi. Pertama, strategi yang disusun didukung dengan teori-teori psikologi dan teori pembelajaran. Kedua, strategi yang disusun menunjukkan efektivitas dalam membuat siswa mencapai tujuan pembelajaran seperti yang telah ditetapkan. Argumentasi ini diperlukan karena didalam pembelajaran dipahami bahwa:" tidak semua materi cocok untuk semua metode, tidak semua materi cocok untuk semua media, tidak semua pembelajaran memerlukan seluruh urutan pembelajaran, urutan kegiatan pembelajaran tergantung pada karakteristik siswa dan jenis perilaku yang ada dalam tujuan pembelajaran". Dengan demikian, dalam menentukan strategi pembelajaran diperlukan pemilihan, dan sedapat mungkin disusun berdasarkan alasan-alasan yang bersifat rasional. 


\section{DAFTAR PUSTAKA}

Afandi, M. 2013. Evaluasi Pembelajaran Sekolah Dasar. Semarang: Unissula Press.

Darmansyah. 2012. Strategi Pembelajaran Menyenangkan Dengan Humor. Jakarta: Bumi

Aksara.

Hamruni. 2012. Strategi dan Model-Model Pembelajaran Aktif Menyenangkan. Yogyakarta: Investidaya.

Ramayulis. 2006. Metodologi Pendidikan Islam. Jakarta: Nusa Media.

Riyanto, Y. 2009. Paradigma Baru Pembelajaran: Sebagai referensi bagi Guru/Pendidik dalam Implementasi Pembelajaran yang Efektif dan Berkualitas. Jakarta: Kencana.

Sanjaya, W. 2007 . Strategi Pembelajaran Berorientasi Standar Peroses Pendidikan. Jakarta: Kencana.

Trianto. 2015. Desain Pengembangan Pembelajaran Tematik Bagi Anak Usia Dini TK/RA \& Anak Usia Kelas Awal SD/MI. Jakarta: PRENADAMEDIA GROUP.

Yamin, M. 2012. Desain Baru Pembelajaran Konstruktivistik.Jakarta: Ciputat Mega Mall.

Zaini, H., dkk.2008. Strategi Pembelajaran Aktif. Yogyakarta: Insan Madani. 